\title{
Review Article \\ Current Status of Indigenous and Highly Productive Chicken Breeds in Ethiopia
}

\author{
Bayesa Tolasa (iD) \\ Werabe University, College of Agriculture and Natural Resource, Department of Animal Science, Werabe, Ethiopia \\ Correspondence should be addressed to Bayesa Tolasa; bayeetola16@gmail.com
}

Received 30 September 2020; Revised 12 December 2020; Accepted 12 July 2021; Published 21 July 2021

Academic Editor: Othmane Merah

Copyright (c) 2021 Bayesa Tolasa. This is an open access article distributed under the Creative Commons Attribution License, which permits unrestricted use, distribution, and reproduction in any medium, provided the original work is properly cited.

In Ethiopia, chicken production plays an important role in providing human food consumption, growth of domestic products, and creating employment opportunities. Despite their importance, the production and reproduction performance of chickens in the country is under expectation owing to the gap between low productive indigenous and low adaptive ability of highly productive chicken breeds. By considering this, the present paper aims to deliver, synthesize, and summarize the compiled information on the current status of indigenous and highly productive chicken breeds. Currently, there are several highly productive chicken breeds available in Ethiopia. Among these, Rhode Island Red, Fayoumi, Potchefstroom Koekoek, Sasso, Bovan Brown, Issa Brown, and Leghorn are being kept under various husbandry systems. Besides, indigenous chicken ecotypes such as barley plumage color, red plumage color, white plumage color, and black plumage color have been characterized in the country. However, the average annual egg production of indigenous and highly productive chicken breeds did not exceed 60 and 250 eggs, respectively. On the other hand, the meat production ability of indigenous chickens is limited as cockerels and pullets may reach 1.5 and 1.05 kilogram live weight at 6 months of age, respectively. Concerning the husbandry system, a majority of owners supplied feed to chickens on the ground and water in plastic containers while scavenging is being the common feeding system in most parts of the country. Furthermore, the majority of the owners are using no separate housing system and treat their chickens traditionally. Thus, awareness should be emphasized on enhancing the improvement of chicken husbandry systems for better production and reproduction performance.

\section{Introduction}

The Ethiopian economy is based on agriculture, and this sector contributes about $42.30 \%$ to the total gross domestic products [1]. From this, $26.40 \%$ of the national gross domestic product is contributed by livestock, including chickens [2]. The total chicken populations of the country is estimated to be about 56.06 million; of this, indigenous $88.19 \%$, exotic $6.45 \%$, and hybrid $5.36 \%$ [3]. The poultry sector in Ethiopia can be characterized into three major production systems based on some selected parameters such as breed, flock size, housing, feeding, health, technology, and biosecurity $[1,3]$. These are large-scale commercial poultry production systems, small-scale commercial poultry production systems, and village or backyard poultry production systems $[3,4]$. Housing is the major important part of the husbandry system for all types of livestock [2]. However, the backyard housing system is being known as a common chicken housing system in Ethiopia [1, 3, 4]. Health care is one of the critical constraints for chicken production in Ethiopia followed by feed resource, predators, and poor marketing information [5-7].

Chicken production plays a crucial role in the provision of affordable animal protein for human food consumption and cash income generating [4]. It also creates an employment opportunity for the youth, elders, and women in rural, periurban, and urban areas [5]. From the total chicken breeds available in the country, indigenous chickens are leading the contribution to the national economy $[6,7]$. However, indigenous chickens are known for their low production performance due to the factors such as slow growth rate, late sexual maturity, and low productivity $[3,4]$. 
To improve the performance of the local chickens, exotic chickens such as White and Brown Leghorns, Rhode Island Red, New Hampshire, Cornish, and Australorp Light Sussex have been introduced to Ethiopia since 1952 [4, 8]. In addition, Bovans Brown, Potchefstroom Koekoek, and Sasso were introduced to the country [9]. However, there are various factors like diseases, predators, lack of proper health care, feed source, and poor marketing information that hinder the productivity of the chickens in most area of the country [10]. For such types of reasons, after improving the chicken population of Ethiopia for nearly 67 years, the total number of hybrid chickens is estimated to be below 6 percent [3].

Consequently, a number of research projects were conducted in different areas of the country for academic and development purposes in the past to assess and improve the productivity of poultry in Ethiopia [4, 8]. However, the information on the production and reproduction performance of poultry breeds in Ethiopia under different husbandry systems has not been fully studied and not well compiled. Therefore, it is important to review the current status of the indigenous and highly productive chicken breeds to deliver, synthesize, and summarize information for the beneficiaries and readers.

\section{Production, Reproduction, and Husbandry System of Chicken Breeds in Ethiopia}

2.1. Chicken Breeds in Ethiopia. There are indigenous and exotic/crossbred/hybrid chicken breeds available in Ethiopia [11]. The indigenous chickens are known for their variation in color, comb type, body conformation, inherent scavenging, nesting habit, and adaptation ability to the harsh environment $[1,7,9]$. There are about ten indigenous chickens available in the country, namely, Chefe and Gebsima (barley plumage color; Figure 1 showing the barley plumage color indigenous ecotypes); Horro, Jarso, and Keyi (red plumage color; Figure 2 showing the barley plumage color indigenous ecotypes); Naked Neck and Netch (white plumage color; Figure 3 showing the white plumage color indigenous ecotypes); Tepi and Tikur (black plumage color; Figure 4 showing the black plumage color indigenous ecotypes); and Tilili [2, 11-13]. Moreover, there are several ecotypes like white-barley, golden-red, black-tailed white, silver and buff/yellow, and indigenous ecotypes (Hailu and Melese, 2018; Figure 5). Although indigenous chickens are appreciated by their adaptation ability to the environment, they are characterized by a slow growth rate, late maturity, and low production performance. With such types of problems, the mean annual egg production of indigenous chickens is less than 60 eggs [2, 9].

Currently, highly productive breeds such as Rhode Island Red, Australorp, New Hampshire, and White Leghorns are being kept in backyard chicken production systems with certain inputs [14]. And also, layer breeds like Bovans Brown and Issa Brown are imported to Ethiopia, which are currently used for egg production [11]. Other breeds such as Fayoumi, Koekoek, Sasso, Red barred, Lohmann Dual, Novo Color, Lohmann Brown, Dominant Sussex, and Novo
Brown are currently available in the country $[9,15,16]$. The attempts to introducing exotic chickens were for improving the productivity of low productive indigenous chickens [11]. Nevertheless, the country poultry producers could not satisfy the expected human food consumption for this long period [8, 9]. Consequently, the productivity of exotic chickens under the Ethiopian condition needs effective evaluation by starting from an intensive to extensive husbandry system.

\subsection{Production Performance}

2.2.1. Egg Production. In Ethiopia, the production performance of chickens is being characterized as low due to little inputs for housing, feeding, and health care management [17]. Also, the high level of mortality rate is another problem [2]. In the case of genotypes, the most dominant chickens reared in Ethiopia are indigenous ecotypes, which show a large variation in body position, plumage color, comb type, and low productivity $[11,12]$. The total egg per year of the indigenous Horro chicken breed varied from 45 to 75 eggs [2]. It is greater than the total eggs per year of other breeds in Ada'a Eastern Ethiopia with the values varying from 45 to 60 eggs [2]. On the other hand, the annual egg production performance of Fayoumi chickens is 144 eggs, which is lower than 185 eggs of Rhode Island Red and 173 eggs of White Leghorn under a smallholder farmer's husbandry system in Northern Ethiopia [5]. Furthermore, the White Leghorn chicken breed performed significantly better as assigned to household conditions with or without supplementation at the stage of age at first egg in Southern Ethiopia [11]. In this way, it could be understood that Rhode Island Red, Fayoumi, and White Leghorn chickens well-performed relatively under scavenging conditions.

2.2.2. Meat Production. Poultry production is affected by factors such as breeds of chicken used, environmental conditions, feeding practices, and husbandry system [4]. Since poultry meat is relatively cheap and provides affordable protein than other animal products such as beef, most consumers are choosing it $[1,2]$. Meat production has direct proportion to growth traits like body weight, feed intake, feed efficiency, and daily gain of the chicken [17]. Nevertheless, the meat production ability of indigenous chickens is limited beyond the needed standard [3,9]. Meanwhile, cockerels and pullets may reach 1.5 and 1.05 kilogram live weight at 6 months of age, respectively [15]. However, most populations of the country keep these indigenous chickens for both meat and egg purposes currently in the country [2]. This could be due to the adaptive ability of the indigenous chickens to low-quality feed and other environmental problems. On the other hand, highly productive breeds such as Rhode Island Red, Sasso, and Koekoek were reported repeatedly as dual-purpose chicken breeds [9, 18], Even though these breeds are being used for egg production more than meat production $[2,3,9]$. Therefore, the improvement of indigenous chicken breeds needs to be 

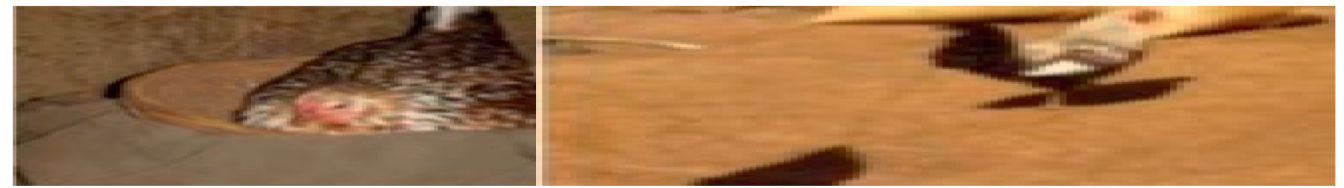

FIGURE 1: Barley plumage color indigenous ecotypes. Source: Solomon, 2008.
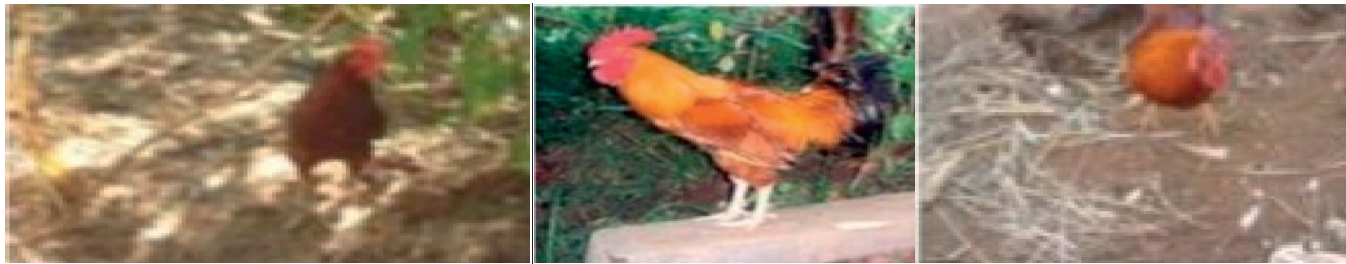

Figure 2: Red plumage color indigenous ecotypes. Source: Dawit et al., 2008.
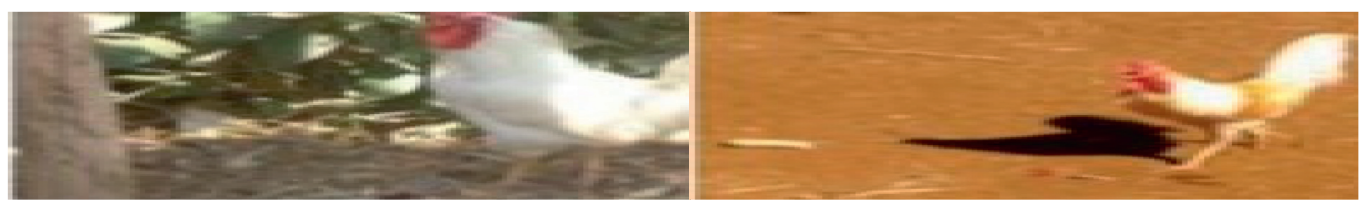

FIgURE 3: White plumage color indigenous ecotypes. Source: Nigussie, 2012.

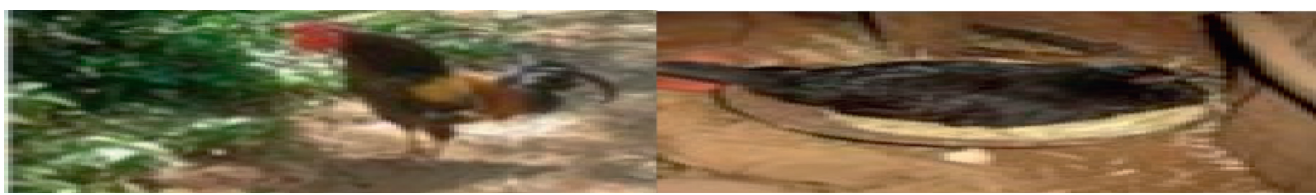

FIgURE 4: Black plumage color indigenous ecotypes. Source: Tamir et al., 2015.
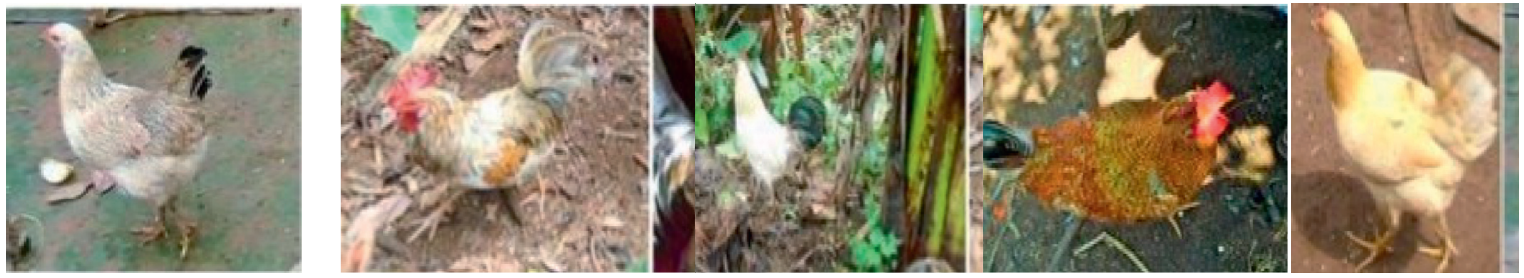

FIGURE 5: White-barley, golden-red, black-tailed white, silver and buff/yellow, and indigenous ecotypes. Source: Hailu and Melese, 2018.

characterized in comprehensive with proper breeding practice and husbandry system.

2.3. Reproduction Performance. To study the reproductive performance, it is very essential to know economically important reproductive traits $[2,4,5,19]$. Among these traits, age at first egg, body weight at first egg, hatchability, and fertility are the major ones $[4,9,11]$. The age at first egg is an important economic trait as it has a direct effect on egg production and sexual maturity [2, 9]. Furthermore, body weight at first egg is another important trait that determines the future productive performance of a hen [12].
The current result revealed that the body weight at first egg was $2730.00 \mathrm{~g}$ for the slow-growing meat-type chickens and $1100.00 \mathrm{~g}$ for Potchefstroom Koekoek in Areka, Southern Ethiopia [9]. However, the mean age at first egg of Potchefstroom Koekoek recorded at each farmer was 142 days [9]. Furthermore, 76.00 and $39.00 \%$ of hatchability of egg collected from indigenous and Rhode Island Red, respectively, in the semiarid Tigrayi region of Northern Ethiopia [5]. On the other hand, the hatchability of indigenous chickens varied from 78.10 to $90.00 \%$ with the expectation that 50.00 to $88.80 \%$ of the chicks hatched would have been survived $[2,3]$. However, the length of the broody period is a major factor that affects productivity [2]. 
2.4. Husbandry System. In Ethiopia, there are three major chicken production systems based on some selected parameters such as breed, flock size, housing, feeding, health, technology, and biosecurity [17]. They are large-scale commercial poultry production system, small-scale commercial poultry production systems, and village or backyard poultry production systems [20]. Large-scale commercial production systems are highly intensive production systems $[1-3,17]$. This system involves an average of greater than or equal to 10,000 chickens kept under indoor conditions with medium to high biosecurity levels $[2,4]$. In addition, these systems are heavily dependent on imported exotic breeds that require intensive inputs such as feed, housing, health, and modern management systems [3]. Furthermore, the existence of somehow better biosecurity practices has reduced chick mortality rates to merely 5 percent [20]. On the other hand, the scavenging production system is characterized by little or no inputs for housing, feeding, and health care with a minimal level of biosecurity [2, 17]. Both indigenous and exotic chicken breeds may be kept under this system with a high off-take rate and high level of mortality [14].

2.4.1. Feeding and Drinking. Although chicken owners offer a supplement to feed their chickens, the scavenging system is being so popular $[7,18]$. The reason why the scavenging system is being so popular may be the effective utilization of locally available feed resources [17]. It plays an important role in converting leftovers, wastes, and insects into valuable and quality protein [2]. In addition, the scavenging feed resource base contains different feeding material, which includes crop seeds, plant material, worms, insects, and undefined materials for improving chicken performance [3]. On the other hand, feed supplementation as a common practice has been reported in many countries including Ethiopia [7, 17, 18]. However, the majority of chicken owners supply feed to chickens on the ground $[12,17]$. Furthermore, about $96 \%$ of farmers provided water to their chickens with free access [16]. Therefore, the scavenging system may seem better as feeding with supplement needs some improvement of the husbandry system.

2.4.2. Housing. Housing is the major important part of the husbandry system for all types of livestock [2, 19, 21]. However, the backyard housing system is being known as the common chicken housing system in Ethiopia [18]. It is rudimentary and mostly built with locally available materials [17]. Moreover, there is no separate house and chickens live together with humans in a traditional free foraging system $[12,17]$. The result indicated that about $77.90 \%$ of the village chicken owners provided only night shelter and only $22.1 \%$ provided a separate chicken house [7]. Another reported result indicated that $41.30 \%$ and $21.20 \%$ of chicken owners share the same chicken house [16]. It indicates that the productivity of chicken may be improved with the proper housing system.
2.4.3. Health Management. Health care is another factor that influences the productivity of chicken $[2,3]$. It is one of the critical constraints for chicken production in Ethiopia followed by feed resource, predators, and poor marketing information $[17,18]$. In Ethiopia, the majority of the owners did not vaccinate their chicken properly [13]. In the same way, most farmers usually treat sick chickens using traditional medicine [7]. This might mean why the Ethiopian indigenous flocks are said to be disease-resistant and adapted to a harsh environment.

2.4.4. Mortality. The mortality rate and survivability of different chickens in the country have been reported by many researchers $[4,5,9,12]$. Based on this, the highest mortality was recorded in Fayoumi (68\%) followed by White Leghorn (49\%) and Rhode Island Red (33.3\%) [5]. In another study, higher survivability was reported in Fayoumi and Rhode Island Red, with a value of 14 and 29 percent, respectively [4]. Moreover, in the Potchefstroom Koekoek chicken breed, averagely about $93.10 \%$ of the chickens survived to the laying age and mortality reduced from 20.20 to $6.90 \%$ [9]. Based on the reviews made, the main causes of mortality might be the ineffectiveness of the vaccine delivered and failure and faulty administration of the vaccine.

\section{Conclusion}

In Ethiopia, chicken production plays a great role by contributing to the growth of domestic products, food consumption, and employment opportunities. Despite this importance, the production and reproduction performance of chickens are low due to factors such as low productivity of indigenous, low adaptive ability of highly productive chickens, and high mortality rate. Also, a substandard husbandry system that more based on a scavenging system is another problem. Moreover, the majority of the owners are using no separate housing system, feeding chicken on the ground, and providing water in a low-quality plastic container, respectively. Besides, lots of the producers treat their chickens in traditional methods. In general, the current status of the production, reproduction, and husbandry system of Ethiopian chickens needs consideration to be given to breeds and awareness for producers. To fulfill the gap between the low productive indigenous and low adaptive ability of highly productive chicken breeds, awareness should be emphasized on treating, housing, feeding, and watering chickens properly.

\section{Conflicts of Interest}

The author declares that there are no conflicts of interest.

\section{Acknowledgments}

The author acknowledges Solomon Demeke (Prof) and Kirmani Ahmed (Prof) for their consistent and stimulating advice, valuable suggestions, and careful guidance. 


\section{References}

[1] World Bank, Ethiopia's Great Run-the Growth Acceleration and How to Pace it, Report No. 99399.ET, The World Bank Group, Washington, DC, USA, 2014.

[2] ILRI (International livestock Research Institute), Unlocking the Potential of Ethiopian Livestock Sector, ILRI, Nairobi, Kenya, 2016, https://news.ilri.org/.../unlocking-the-\% 20potential-of-the-.

[3] Central Statistics Agency (CSA), "The federal democratic republic of Ethiopia," Agricultural Sample Survey. Vol. II. Report on Livestock and Livestock Characteristics (Private Peasant Holdings), CSA, Addis Ababa, Ethiopia, 2017.

[4] S. Tamir, Y. Moges, and H. Tilahun, "Determinants of adoption of exotic poultry breeds among smallholder poultry producers in North Western Amahara Region, Ethiopia," Global Science Research Journals, vol. 3, pp. 162-168, 2015.

[5] L. Abraham and T. Yayneshet, "Performance of exotic and indigenous poultry breeds managed by smallholder farmers in northern Ethiopia," Livestock Research for Rural Development, vol. 22, p. 133, 2010.

[6] C. Ruxton, "Value of eggs during pregnancy and early childhood," Nursing Standard, vol. 27, no. 24, pp. 41-50, 2013.

[7] F. Moges, A. Mellesse, and Dessie, "Assessment of village chicken production system and evaluation of the productive and reproductive performance of local chicken ecotype in Bure district, North West Ethiopia," African Journal of Agricultural Research, vol. 5, pp. 1739-1748, 2010.

[8] D. Nigussie, Breeding programs for indigenous chicken in Ethiopia: analysis of diversity in production systems and chicken populations, $\mathrm{PhD}$ Thesis, Wageningen University, Wageningen, the Netherlands, 2011.

[9] G. Aman, B. Bangu, Z. Bereket et al., "Production performance of Sasso (distributed by ethio-chicken private poultry farms) and Bovans brown chickens breed under village production system in three agro-ecologies of Southern Nations, Nationalities, and Peoples Regional State (SNNPR), Ethiopia," International Journal of Livestock Production, vol. 8, no. 9, pp. 145-157, 2017.

[10] T. Natnael, "Pathological and sero prevalence studies on infectious bursal disease in chickens in and around Bahir Dar, North West, Ethiopia," M.Sc. Thesis, Addis Ababa University, College of Veterinary Medicine and Agriculture, Department of Pathology and Parasitology, Bishoftu, Ethiopia, 2015.

[11] D. Solomon, Ethiopian Poultry Sector Country Review, http:// $\mathrm{ftp} / / / \mathrm{ftp}$.fao.org/docrep/fao/011/ai320e/ai320e00.pdf, FAO, Rome, Italy, 2008, http://ftp://ftp.fao.org/docrep/fao/011/ ai320e/ai320e00.pdf.

[12] T. Getachew, E. Kebede, N. Ameha, and T. Terefe, "Village chicken husbandry practice, marketing and constraints in eastern Ethiopia," The Journal of World's Poultry Research, vol. 5, no. 4, pp. 104-108, 2015.

[13] H. Assefa and A. Melesse, "Morphological and morphometric characterization of indigenous chicken populations in Sheka zone, South Western Ethiopia," Poultry, Fisheries \& Wildlife Sciences, vol. 6, no. 2, p. 200, 2018.

[14] D. Alemu, T. Degefe, S. Ferede, S. Nzietcheung, and D. Roy, Overview and background paper on Ethiopia's poultry sector: Relevance for HPAI research in Ethiopia, 2008, https://hdl. handle.net/10568/488.

[15] K. Bogale, "In situ characterization of local chicken eco-type for functional traits and production system in Fogera district, Amahara regional state," M.Sc. Thesis, Department of Animal
Science School of Graduate Studies, Haramaya University, Dire Dawa, Ethiopia, 2008.

[16] T. Desalew, "Management practice, productive performance and egg quality traits of exotic chickens under village production system in East Shoa zone," Msc. Thesis, Addis Ababa University College of veterinary medicine and Agriculture, Addis Ababa, Ethiopia, 2012.

[17] M. Ahmed, "“Major constraints and health management of village poultry production in Ethiopia": review School of Veterinary Medicine, Jimma university, Jimma, Ethiopia," International Journal of Research Studies in Microbiology and Biotechnology, vol. 4, no. 1, pp. 1-10, 2018.

[18] M. Mengesha, B. Tamir, and T. Dessie, "Village chicken constraints and traditional management practices in Jamma District, South Wollo, Ethiopia," Livestock Research for Rural Development, vol. 23, no. 37, 2011.

[19] A. Ghayas, J. Hussain, A. Mahmud, M. H. Jaspa, H. M. Ishaq, and A. Hussain, "Behaviour, welfare, and tibia traits of fastand slow-growing chickens reared in intensive and free range systems," South African Journal of Animal Science, vol. 51, no. 1, 2021.

[20] J. Bush, The Threat of Avian Flu-Predicted Impacts on Rural Livelihoods in Southern Nation, Nationalities and Peoples Region (SNNPR) of Ethiopia, The Food Economy Group, London, UK, 2006.

[21] A. Ghayas, J. Hussain, A. Mahmud, and M. H. Jaspal, "Evaluation of three fast- and slow-growing chicken strains reared in two production environments," South African Journal of Animal Science, vol. 50, no. 3, pp. 378-388, 2020. 